\title{
Researches on hybrid Phlomis $x$ termessi P.H. Davis in Göynük province of Antalya
}

\author{
Ayşe Gül Sarıkaya a,", Hüseyin Fakir ${ }^{\text {b }}$
}

\begin{abstract}
In this study that was conducted during the vegetation period of 2016, determination to morphological characteristics and volatile components in volatile components in the leaves and flowers of Phlomis x termessi P.H. Davis were aimed. For determining to volatile components leaves and flowers were collected from Göynük-Antalya in three different periods that were pre-flowering, flowering and post-flowering periods and volatile components were determined through SPME (solid-phase microextraction method) analysis. 57 different volatile components were identified from P. x termessi, while it was also found that the rate of volatile components was higher during the flowering period, and $\alpha$-pinene, limonene, $\beta$ - caryophyllene and germacrene-D were found to be the main components. Furthermore, with a view to measuring the morphological features of $P . x$ termessi, width-height of 50 leaf samples and the length of leaf stalks were measured; while the calyx height of 50 calyxes samples collected, the length of calyx teeth, bracteole length and the length of corolla were measured and the mean values were calculated. As result of morphological characteristics, means of leaf length, leaf width, petiole, calyx, calyx teeth, bracteole and corolla were measured as $4.55 \pm 1.65,1.78 \pm 0.89,2.56 \pm 1.55,1.17 \pm 0.18,0.35 \pm 0.11,1.31 \pm 0.40$ and $2.04 \pm 0.30$ respectively.
\end{abstract}

Keywords: Phlomis $x$ termessi, Hybrid, Morphology, Volatile component, Göynük, Antalya

\section{Antalya Göynük Yöresinde hibrit Phlomis $x$ termessi P.H. Davis üzerine araştırmalar}

\begin{abstract}
Özet: 2016 y1lı vejetasyon döneminde gerçekleștirilen çalışmada, Antalya ili Göynük mevkiinden toplanmış Phlomis x termessi P.H. Davis'nin uçucu bileşenlerinin ve morfolojik özelliklerinin tespit edilmesi amaçlanmıştır. Uçucu bileşenlerin belirlenmesi için yaprak ve çiçekler çiçeklenme öncesi dönem, çiçeklenme dönemi ve çiçeklenme sonrası dönem olmak üzere bir yıl içerisinde 3 farklı zamanda toplanmış ve uçucu bileşenleri SPME (katı tabanlı mikroekstraksiyon yöntemi) analizi ile belirlenmiştir. $P . x$ termessi'de 57 farklı uçucu bileşen tespit edilmiş olup, çiçeklenme döneminde bileşen oranının yüksek olduğu ve $\alpha$-pinen, limonen, $\beta$ - karyofilen ve germakren-D ana bileşenler olarak bulunmuştur. Ayrıca $P . x$ termessi'nin morfolojik ölçümlerini hesaplamak için bu türe ait 50 yaprak örneğinin en-boy ölçümleri, yaprak sapı uzunluğu; toplanmış olan örneklere ait kalikslerin boyu, kaliks dişi boyu, brakteol boyu ve korollanın boyu ölçülmüş ve ortalama değerleri belirlenmiştir. Morfolojik ölçümlerin sonucuna göre, ortalama yaprak boyu $4.55 \pm 1.65$, yaprak eni $1.78 \pm 0.89$, yaprak sapı uzunluğu $2.56 \pm 1.55$, kaliks boyu $1.17 \pm 0.18$, kaliks dişi boyu $0.35 \pm 0.11$, brakteol boyu $1.31 \pm 0.40$, ve korolla boyu ise $2.04 \pm 0.30$ olarak ölçülmüştür.

Anahtar kelimeler: Phlomis x termessi, Hibrit, Morfoloji, Uçucu bileşen, Göynük, Antalya
\end{abstract}

\section{Introduction}

Turkey that is located at the intersection between three phytogeographical zones has a high species endemism due to the ecological and geographical differentiation since it is positioned between South European and Southwest Asian floras and the origin and differentiation centre of several genera and sections are located in Asia Minor (Tan, 1992). Approximately 3649 plant taxa out of 11466 that grow naturally in Turkey are endemic. Hundreds of plant species that grow naturally in Turkey including primarily the endemic ones have a very high medicinal and aromatic value (Güner, 2012).

The history of medicinal plants is observed to be as old as the history of humankind. In the last 5000 years, the historical artifacts that remained from all civilizations show that plants were used for the treatment of diseases. Such civilizations include Assyrians, Sumerians, Hittites, ancient Egyptians and Roman, Greek, Byzantine and Ottoman civilizations from the near history. The use of plants to treat diseases by people dates back to very old times. In ancient China, India, Egypt Iran, Greece and some European countries, people believed that plants had a healing effect while treating the diseases (Başer, 2007). Treatment of diseases with plants has been transferred to our age from very old days. In Turkish history, texts about the Physician Lokman and also the mythological belief that plants could find a cure for death increased the interest of people in these plants that grew naturally and the medicines made from these plants. Cultivation of medicinal plants also contributed to the development of this field of science. By the late $19^{\text {th }}$ century, the cultivation of medicinal products lost ground due to the major developments in the field of chemistry;

\footnotetext{
$\bowtie$ a Suleyman Demirel University, Atabey Vocational School, Isparta, Türkiye

b Suleyman Demirel University, Faculty of Forestry, Forest Engineering Department, Isparta, Türkiye 
however, it did not diminish the interest in these plants (Erdemir, 1998).

Nearly 20 thousand out of 300 thousand flowery and seedy plants that are registered across the world currently are appropriate for medical purposes, around 4000 herbal drugs are intensively used and especially around 500 of them are traded for commercial purposes (Baydar, 2009).

Aromatic plants are used for several purposes such as tea, spices, seasonings, and volatile components. These components (extracts, etheric oils) and aromatic extracts are commonly used by the fragrance and flavour industries to manufacture perfumes, food additives, cleaning substances, cosmetics and drugs, as the source of aromatic chemicals or as the synthesis initiator of nature identical and semisynthetic beneficial aromatic chemicals (Başer, 2000).

Those medical and aromatic plants that especially contain abundance of volatile components are of great importance. There has been an increased demand to the essential oils in the aromatherapy sector in recent years (Weiss, 1997).

The interest of the people in medicinal and aromatic plants also increased. Phlomis L. that is also commonly used by people is a very important medicinal and aromatic plant that is naturally distributed in Turkey and it is one of the genera that have the highest number of species with around 100 species across the world in Lamiaceae family. This genus is distributed across Asia, South Europe and North Europe (Matthiesen et al., 2011). Its leaves and flowers are savory, anti-allergic, diuretic, diarrhoea suppressant, carminative, and used to treat stomach disorders and as pain-killers, anti-diabetic herbal tea and tonic. Moreover, it is also known to be used by people for respiratory tract disorders and haemorrhoids (Harput et al., 2006).

The purpose of this study was to determine the morphological characteristics, essential oil components of Phlomis $x$ termessi that is the hybrid of $P$. bourgaei $x P$. lycia distributed in Antalya-Göynük and the effect of collection at different stages on essential oil components and find the best collection time.

\section{Material and method}

\subsection{Morphological measurement method for Phlomis $x$ termessi P.H. Davis (P. bourgaei $x$ P. lycia)}

Field studies were conducted in Göynük province ( $\mathrm{N}$ $36^{\circ} 44^{\prime}$, E $30^{\circ} 33^{\prime} ; 35 \mathrm{~m}$ ) of Antalya where Phlomis $x$ termessi was distributed and the sampling plots on these locations (Figure 1) were identified in vegetation period of 2016. Then, sampling plots were identified in the dimension of $20 \times 20 \mathrm{~m}$ and plant samples were collected from these plots to be stored in the herbarium.

Phlomis $x$ termessi is a bush that can grow up to the height of $150 \mathrm{~cm}$ and has glandular hair or rarely does not have glandular hair. Leaf, flower and calyx samples were collected from the sampling plots in order to determine the morphological characteristics of P. x termessi. In order to measure the morphological characteristics of $P . x$ termessi, the width-height of 50 samples from each sampling point and the length of leaf stalks were measured with a digital calliper; the width and height of 50 calyxes contained in the collected samples, calyx teeth height, bracteole length and corolla height were also measured.
2.2. Method to determine the essential oil components in the leaves and flowers of Phlomis $x$ termessi P.H. Davis ( $P$. bourgaei $x$ P. lycia)

Samples were collected from the sampling plots that were identified in 3 different vegetation periods which were pre-flowering (April), flowering (June) and post-flowering (August) periods. The leaf and flower samples that were collected were placed in paper packages and transported to the laboratory on the same day without a delay and without exposure to sunlight. The plant materials that were collected were dried at room temperature $\left(25^{\circ} \mathrm{C}\right)$. The dried flower and leaf samples of Phlomis $x$ termessi were subjected to solid phase microextraction (SPME, Supelco, Germany) with a fibre precoated with a $75 \mu \mathrm{m}$-thick layer of Carboxen/Polydimethylsiloxane (CAR/PDMS). $2.0 \mathrm{~g}$ of samples newly hand-picked was put into a $10 \mathrm{~mL}$ vial, which was then immediately sealed with a silicone septum and a crimp cap. After incubation for $30 \mathrm{~min}$ at $60^{\circ} \mathrm{C}$, SPME fibre was pushed through the headspace of a sample vial to adsorbed the volatiles, and then inserted directly into the injection port of the GC-MS (Shimadzu 2010 Plus GC-MS with the capillary column, Restek Rxi ${ }^{\circledR}-5$ Sil MS $30 \mathrm{~m}$ x $0.25 \mathrm{~mm}, 0.25 \mu \mathrm{m}$ ) at a temperature of $250^{\circ} \mathrm{C}$ for desorption ( $5 \mathrm{~min}$ ) of the adsorbed volatile compounds for analysis. Identification of constituents was carried out with the help of retention times of standard substances by composition of mass spectra with the data given in the Wiley, NIST Tutor, FFNSC library. LRIs (Linear Retention Indices) were calculated by using a series of the standards of C7-C30 saturated n-alkanes (Sigma-Aldrich Chemical Co., USA) for reference in the same column and conditions as described above for GC-MS analysis.

\section{Results}

\subsection{Morphological characteristics of Phlomis $x$ termessi P.H. Davis}

In order to measure the morphological characteristics of Phlomis $x$ termessi, the width-height of 50 samples from each sampling point and the length of leaf stalks were measured with a digital calliper; the width and height of 50 calyxes contained in the collected samples, calyx teeth height, bracteole length and corolla height were also measured and the mean values were calculated (Table 1).

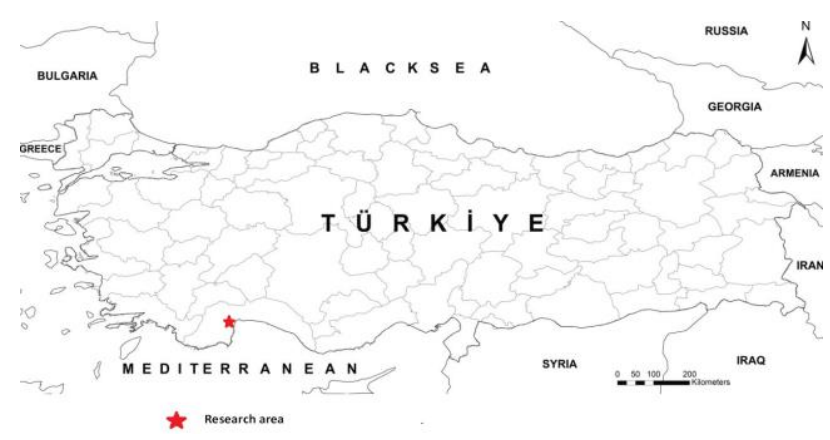

Figure 1. Collecting site of Phlomis x termessi leaves and flowers 
Table 1. Measured Values of the Leaves and Calyxes of Phlomis $x$ termessi P.H. Davis

\begin{tabular}{|c|c|c|c|}
\hline \multicolumn{4}{|c|}{ Phlomis $\mathrm{x}$ termessi P.H. Davis } \\
\hline Values & $\begin{array}{l}\text { Minimum } \\
(\mathrm{cm})\end{array}$ & $\begin{array}{l}\text { Maximum } \\
(\mathrm{cm})\end{array}$ & Mean \pm std. dev. $(\mathrm{cm})$ \\
\hline Leaf Width & 0.6 & 4.2 & $1.78 \pm 0.89$ \\
\hline Leaf Lenght & 1.2 & 8.0 & $4.55 \pm 1.65$ \\
\hline Petiole & 0.3 & 5.5 & $2.56 \pm 1.55$ \\
\hline Calyx & 1.0 & 1.6 & $1.17 \pm 0.18$ \\
\hline Calyx teeth & 0.2 & 0.6 & $0.35 \pm 0.11$ \\
\hline Bracteole & 0.9 & 2.1 & $1.31 \pm 0.40$ \\
\hline Corolla & 1.5 & 2.5 & $2.04 \pm 0.30$ \\
\hline
\end{tabular}

3.2. Volatile Components in the leaves and flowers of Phlomis x termessi P.H. Davis (P. bourgaei x P. lycia)

Volatile components in the leaves and flowers of Phlomis $x$ termessi P.H. Davis collected from GöynükAntalya in three different periods that were pre-flowering, flowering and post-flowering periods were determined through SPME (solid-phase microextraction method) analysis. 57 different essential oil components were identified from $P$. $x$ termessi, while it was also found that the rate of the essential oil components was higher during the flowering period, and $\alpha$-pinene, limonene, $\beta$ caryophyllene and germacrene-D were found to be the main components. During the pre-flowering period, the rates of $\alpha$ pinene, limonene, $\beta$ - caryophyllene and germacrene-D were $14.73 \%, 17.08 \%, 17.16 \%$ and $10.82 \%$, respectively, while they were $15.12 \%, 18.44 \%, 19.97 \%$ and $19.53 \%$, respectively, during the flowering period and $9.67 \%, 16.83$ $\%, 18.81 \%$ and $19.25 \%$, respectively during the postflowering period.

Table 2. Volatile components in the leaves and flowers of Phlomis x termessi P.H. Davis

\begin{tabular}{|c|c|c|c|c|c|}
\hline \multicolumn{6}{|c|}{ Phlomis $\mathrm{x}$ termessi P.H. Davis } \\
\hline No & Components & Retantion time & Pre-flowering & Flowering & Post-flowering \\
\hline 1. & dimethyl sulfide & 1.326 & - & - & 0.23 \\
\hline 2. & 2-methylpropanal, & 1.435 & 0.13 & - & 0.33 \\
\hline 3. & 2-butenal & 1.874 & - & - & 0.07 \\
\hline 4. & 3-methylbutanal & 1.920 & 0.17 & - & 0.17 \\
\hline 5. & 2-methylbutanal & 1.997 & 0.11 & - & 0.16 \\
\hline 6. & ethyl vinly ketone & 2.184 & 0.12 & - & 0.25 \\
\hline 7. & 2-ethylfuran, & 2.344 & 0.56 & - & - \\
\hline 8. & sorbaldehyde & 2.392 & - & - & 0.90 \\
\hline 9. & (E)-2-pentenal & 3.166 & - & - & 0.12 \\
\hline 10. & n-hexanal & 4.090 & 0.61 & 1.58 & 1.14 \\
\hline 11. & (E)-2-hexenal & 5.515 & 5.86 & 7.76 & 7.22 \\
\hline 12. & Z-3-hexenol & 5.576 & 0.35 & - & 0.31 \\
\hline 13. & cis-3-hexene-1-ol & 5.654 & - & 0.87 & - \\
\hline 14. & 1,2,4,4-tetramethylcyclopentene & 5.755 & 0.15 & - & - \\
\hline 15 . & 3,3-dimethyl-1-phenylbutane & 6.435 & - & 0.52 & - \\
\hline 16. & heptanal & 7.015 & 0.26 & - & 0.20 \\
\hline 17. & $\alpha$-thujene & 7.835 & 2.23 & - & 1.45 \\
\hline 18. & $\alpha$-pinene & 8.060 & 14.73 & 15.12 & 9.67 \\
\hline 19. & benzaldehyde & 9.042 & 0.25 & - & - \\
\hline 20. & phenylmethanal & 9.555 & - & 0.57 & - \\
\hline 21. & $\beta$-phellandrene & 9.610 & 0.49 & - & 0.29 \\
\hline 22. & $\beta$-pinene & 9.508 & 1.03 & - & 0.50 \\
\hline 23. & Vinyl amyl carbinol & 9.869 & 0.97 & 1.09 & 0.22 \\
\hline 24. & $\beta$-myrcene & 10.206 & 2.89 & 1.09 & 2.52 \\
\hline 25. & n-octanal & 10.708 & 0.29 & - & - \\
\hline 26. & $\alpha$-phellandrene & 10.760 & 1.21 & 0.72 & 1.27 \\
\hline 27. & trans-2,4-heptadienal & 10.969 & 0.25 & 0.34 & 0.21 \\
\hline 28. & p-dichlorobenzene & 11.087 & - & - & 0.21 \\
\hline 29. & $\alpha$-terpinene & 11.176 & 1.71 & 0.55 & 1.76 \\
\hline 30. & p-cymene & 11.469 & 0.79 & - & 0.76 \\
\hline 31. & limonene & 11.693 & 17.08 & 18.44 & 16.83 \\
\hline 32. & B-ocimene & 11.995 & 0.48 & 0.45 & 0.28 \\
\hline 33. & Benzene & 11.999 & - & 1.12 & - \\
\hline 34. & 1,4-cyclohexadiene & 12.876 & 0.59 & - & - \\
\hline 35. & $\gamma$-terpinene & 13.337 & - & 0.31 & - \\
\hline 36. & $\alpha$-terpinolene & 13.811 & 2.65 & 0.68 & 2.30 \\
\hline 37. & n-nonanal & 14.609 & 0.78 & 0.39 & 0.23 \\
\hline 38. & $\alpha$-cubebene & 23.507 & 6.95 & 1.24 & 1.06 \\
\hline 39. & $\alpha$-ylangene & 24.360 & - & - & 0.18 \\
\hline 40. & $\alpha$-copaene & 24.468 & 1.61 & 0.93 & 1.40 \\
\hline 41. & $\beta$ - bourbonene & 24.734 & 0.56 & 1.07 & 0.81 \\
\hline 42. & $\beta$-cubebene & 24.897 & 0.26 & 1.31 & - \\
\hline 43. & B-elemene & 24.960 & 0.25 & 0.39 & 0.68 \\
\hline 44. & $\alpha$-gurjunene & 25.540 & 0.37 & - & 0.36 \\
\hline 45. & $\beta$-caryophyllene & 26.000 & 17.16 & 19.97 & 18.81 \\
\hline 46. & 6-cadina-1 & 27.321 & 1.44 & - & 0.24 \\
\hline
\end{tabular}




\begin{tabular}{|c|c|c|c|c|c|}
\hline \multicolumn{6}{|c|}{ Phlomis $\mathrm{x}$ termessi P.H. Davis } \\
\hline No & Components & Retantion time & Pre-flowering & Flowering & Post-flowering \\
\hline 47. & $\gamma$-gurjunene & 27.025 & 0.37 & - & - \\
\hline 48. & $\alpha$-humulene & 27.243 & 1.11 & 1.95 & 1.09 \\
\hline 49. & epi-bicyclosesquiphellandrene & 27.452 & 0.32 & - & 1.25 \\
\hline 50. & germacrene-D & 27.956 & 10.82 & 19.53 & 19.25 \\
\hline 51. & $(-)$ - $\alpha$-muurolene & 28.552 & 0.30 & - & 0.30 \\
\hline 52. & cedr-8-e & 28.555 & 0.28 & - & - \\
\hline 53. & $\gamma$-cadinene & 28.975 & 0.56 & - & 0.97 \\
\hline 54. & $\delta$-cadinene & 29.163 & 0.90 & 1.36 & 1.16 \\
\hline 55. & germacrene B & 30.394 & - & - & 2.85 \\
\hline 56. & (+)-spathulenol & 30.595 & - & 0.92 & - \\
\hline 57. & heptadecane (CAS) n-heptadecane & 40.619 & - & 0.31 & - \\
\hline
\end{tabular}

\section{Discussion and conclusion}

The size of the leaves of Phlomis $x$ termessi P.H. Davis was found to be $1.2-8 \times 0.6-4.2 \mathrm{~cm}$, the leaf stalks were up to $5.5 \mathrm{~cm}$, bracteoles were $0.9-2.1 \mathrm{~cm}$, calyxes were 1.0-1.6 $\mathrm{cm}$, calyx teeth were $0.2-0.3 \mathrm{~cm}$, and corollas were $1.5-2.5$ $\mathrm{cm}$. In the study of Dadand (2002), the leaves of Phlomis $x$ termessi were found to be $1.2-7.5 \times 0.5-3.0 \mathrm{~cm}$, leaf stalks were up to $3 \mathrm{~cm}$, bracteoles were $0.7-1.7 \mathrm{~cm}$, calyxes were $1.0-1.5 \mathrm{~cm}$, calyx teeth were $0.05-0.3 \mathrm{~cm}$, and corollas were 2.1-2.9 $\mathrm{cm}$. Those values were different from the leaf size, leaf stalk, bracteole, calyx and corolla values found in our study.

Phlomis $x$ termessi was found to have 57 different essential oil components, while the main components were $\alpha$-pinene $(15.12 \%)$, limonene (18.44\%), $\beta$ - caryophyllene $(19.97 \%)$ and germacrene-D $(19.53 \%)$. The literature review showed that there was no study conducted to determine the essential oil components of $P$. x termessi that is the hybrid of $P$. bourgaei and $P$. lycia. However, any studies about volatile components of this hybrid, there are studies conducted to determine the essential oil components of $P$. bourgaei and P. lycia. Sarıkaya (2015) identified 62 essential components of $P$. bourgaei through SPME analysis, while the main components of $P$. bourgaei were found to be $\alpha$-cubebene (\%16.04), $\beta$-caryophyllene (\%21.98) and germacrene-D (\%15.12). Sarıürkçü et al. (2013) conducted this study in order to determine the chemical components and antioxidant potentials of the essential oil derived from the endemic species $P$. bourgaei used as household remedy in Turkey through hydrodistillation. They found that the most important and dominant components were $\beta$-caryophyllene (\%37.37), (Z)$\beta$-farnesene (\%15.88) and germacrene-D (\%10.97). Başer et al. (2008) found that germacrene-D (\%11.3) and $\beta$ caryophyllene $(\% 11.2)$ were the main components of $P$. bourgaei. The other studies also found that $\beta$-caryophyllene and germacrene-D were the main components. Contrary to the abovementioned studies, we also found $\alpha$-pinene and limonene were among the main components in our study. Sarıkaya (2015) identified 62 essential oil components of $P$. lycia through SPME analysis while the main components of P. lycia were limonene (\%17.68), $\beta$-caryophyllene (\%23.66) and germacrene D (\%21.88). Sarıkaya and Fakir (2017) identified 57 different essential oil components in P. lycia, while the main components were found to be (E)-2-hexenal (\%8.35), (E)- $\beta$ - farnesene (\%10.05) and germacrene-D (\%45.73). Studies showed that Limonene, $\beta$-caryophyllene and germakren-D were the main components. Unlike these studies, we also found that $\alpha$-pinene was among the main components in our study.

The morphological characteristics and essential oil components of Phlomis $x$ termessi P.H. Davis were identified in our study. Moreover, the essential oil components of the samples collected during three different vegetation periods were identified and it was found that the rate of the components was higher during the flowering period. Therefore, the collection time was also determined for the collectors. In conclusion, there is a need for further studies on hybrid species. They will contribute to the improvement of knowledge on flora and morphological characteristics. Moreover, the areas where these plants can be used will also be determined through the identification of essential oil components.

\section{References}

Başer, K.H.C., 2000. The bright future of essential oils. Medicinal and Aromatic Plants Bulletin, 15: 20-34.

Başer, K.H.C., 2007. Medical plants and health, www.derki.com/hekim/tıbbi-bitkiler-ve-sagligimiz.

Başer, K.H.C., Demirci, B., Dadand,, M.Y., 2008. Comparative essential oil composition of the natural hybrid Phlomis $x$ vuralii Dadand (Lamiaceae) and its parents. Journal of Essential Oil Research, 20: 57-62.

Baydar, H., 2009. Medical and Aromatic Plant Science and Technology. Süleyman Demirel Üniversitesi, Isparta.

Dadand1, M.Y., 2002. The Revision of the genus Phlomis L. (Lamiaceae) of Turkey. PhD Thesis, Gazi University, Ankara.

Demirhan Erdemir, A., 1998. Horse Chestnut and Prepagel The Wonder of Nature. Nobel Press, Istanbul.

Güner, A., 2012. A Checklist of the Flora of Turkey (Vascular Plants). Nezahat Gökyiğit Botanical Garden Press., Istanbul.

Harput, Ü.Ş., Çalış, İ., Saraçoğlu, İ., Dönmez, A.A., Nagatsu, A., 2006. Secondary metabolites from Phlomis syriaca and their antioxidant activities. Turkish Journal of Biology, 30: 383-390.

Mathiesen, C., Scheen, A.C., Lindqvist, C., 2011. Phylogeny and biogeography of the lamioid genus Phlomis (Lamiaceae). The Board of Trustees of the Royal Botanic Gardens, Kew, 66: 83-89.

Sarıkaya, A.G., 2015. Effects of different collecting periods and some habitat properties on volatile components of natural Phlomis L.(Lamiaceae) taxa in the Lakes district. PhD. Thesis, Suleyman Demirel University, Isparta.

Sarıkaya, A.G., Fakir, H., 2017. The volatile components of Phlomis lycia D. Don and Phlomis leucophracta P.H. 
Davis \& Hub.-Mor. species natural distributed in Göynük district of Antalya province. I. International Congress on Medicinal and Aromatic Plants "Natural and Healthy Life", 10-12 May 2017, Konya, p. 624.

Sarikürkçü, C., Özer, M.S., Çakır, A., Eskici, M., Mete, E., 2013. GC/MS Evaluation and In Vitro Antioxidant Activity of Essential Oil and Solvent Extracts of an Endemic Plant Used as Folk Remedy in Turkey: Phlomis bourgaei Boiss. Hindawi Publishing Corporation Evidence-Based Complementary and Alternative Medicine, 2013, 7s.
Tan, A. 1992. Plant diversity and plant genetic resources in Turkey. Anadolu Journal of AARI, 2: 50-64.

Weiss, E.A., 1997. Essential oil crops. The Journal of Agricultural Science, 129: 121-123. 